Abulad's Postmodern Eyes ${ }^{1}$

\title{
Fleurdeliz R. Altez-Albela
}

\begin{abstract}
This short piece is a tribute to Romualdo E. Abulad as an educator and icon of academic philosophy in the Philippines. Abulad's take on postmodernity is presented a critical attitude against the backdrop of the contemporary human situation, as opposed to a historically-specific philosophical system. The following characteristics of Abulad's brand of postmodernism are outlined: via negativa as a way of thinking, a paradigm shift motivated by the refusal to accept metanarratives, dialogical philosophy, intersubjectivethereby, ethical. Ultimately, this paper underscores Abulad's radical critique of the present-a revaluation, of sorts, of the contemporary role of philosophy. Moreover, it is a testimony to Abulad's pedagogy of postmodernity - that is to say, of how he teaches his students to think with postmodern eyes: an openness to the "otherwise than said" that is a profound gesture of hospitality and, yet, a relentless critique.
\end{abstract}

Keywords: Abulad, Filipino philosophy, postmodernism, postmodernity

I

$f$ there is something that I would like to remember about Romualdo E. Abulad, that would be his inquisitive pair of eyes. I have always managed to grab golden chances during my college days whenever we had oral examinations. It was during those revalidas where Abulad (or Brother Romy, as we fondly called him) made me realize the true meaning of a "phenomenological" look. To me, his eyes looked probing, as though I (the examinee) was a book he was carefully and patiently reading. While I grope (and hope) for the (right) answers, I remember how his eyes, while halfclosed, have generously given me their full attention, as they open wide as I

${ }^{1}$ Editor's note: An early version of this piece was delivered as a tribute to Romualdo E. Abulad at the Legacy Lectures of the Philosophical Association of the Philippines, De La Salle University, Manila, October 2012. It appears here, in revised form, to pay homage to Abulad on the occasion of his death on 17 December 2019.

(c) 2019 Fleurdeliz R. Altez-Albela

https://www.kritike.org/journal/issue 25/altez-albela december2019.pdf

ISSN 1908-7330

(cc) $\mathrm{BY}-\mathrm{NC}-\mathrm{ND}$ 
recited and start hitting the right answers. The recitation ends with his reassuring smile.

Yet, despite Abulad's overwhelming phenomenological stare, I would still love to look at his eyes, even if his probing stare could be spinechilling at times, as they encouraged me to put up a good fight. These eyes never failed to challenge as they always seem to speak, "yes, you're getting there ... of course, you'll make it. You have to make it." These are the same words that his eyes spoke beyond oral examinations, and that was after college, whenever we meet and tell him about our adventures and mishaps, victories and heartbreaks. Still, these eyes won't give any answer, but would instead give a consoling sense of hospitality and appreciation about the paths we have chosen and lives that we have made. Through his gaze, I have experienced how this mentor welcomed not just the right answer but "my response," not just "the path" but "my path" and not just "a" or "the" work, but "my work," "my story," "my narrative," "my life."

To me, Abulad's eyes most importantly reflected how they concretely represented the spirit of "postmodernism." Members of the Filipino philosophical community recognize Abulad's contribution to this discourse, as he spoke about postmodernism with "eyes wide opened." At the core of his discussion of postmodernism, Abulad highlights the role of human reason (in the truest Kantian sense), a profound sense of respect for intellectual history, and a full openness to interdisciplinary dialogue.

For Abulad, postmodernism is not simply a school of thought, as he considers it a consciousness which includes the unconscious. It is a way of thinking, a perspective or better yet, a mode of life and thought that reveals the contemporary situation. While "contemporary" is a safe term that may apply to any historical period as long as it speaks of the present, he understands the postmodern against the backdrop of Modernity, a philosophically anthropocentric age that is directly identified with the Cartesian cogito. The postmodern spirit dialectically results from paradigm shifts spurred by a certain collective intellectual clamor situated in a particular time. Abulad makes us realize that such situation involves a cleansing of the Cartesian ego, rendering postmodernity as the period of the "post-man" that is, nevertheless, still about humanity. In his essay, "What is Postmodernism?," he says: "Two things, actually, are taking place. The first is the thorough cleansing of the ego; the second is the emergence of the ego itself as the pure residue after the cleansing." ${ }^{2}$ The ego must be subjected to that total postmodern overhaul because it is only through such irreverent and

${ }^{2}$ Romualdo E. Abulad, “What is Postmodernism?" Karunungan: A Journal of Philosophy, 17 (2000), 23.

(c) 2019 Fleurdeliz R. Altez-Albela https://www.kritike.org/journal/issue 25/altez-albela december2019.pdf ISSN 1908-7330 


\section{ABULAD'S POSTMODERN EYES}

revolutionary change where the present humanity can "find new trails of human consciousness" and "alter the global culture."

Abulad understands this overhaul via negativa, which, as he puts it, a conditio sine qua non to any historical shift, as it is obviously most applicable to this philosophical period. Postmodernism emerged because the egoism of anthropocentricity simply just had to die. Abulad finds this particularly obvious in Nietzsche with his relentless yet necessary declaration of the worst sacrilege that the human ego has committed - the Death (nay, murder) of God. For Abulad, Nietzsche is the initiator of the negativistic consciousness, that most of us are scared of, but can (ironically) easily get away with. As, "the first thing to remember about post-modernity, that its initial essential component is negative or, if you wish, destructive, or more benignly, deconstructive. The invitation is, before anything else, to abolish everything," which is probably summarized by Abulad's first daunting command: "to let go-let everything go!" Echoing Nietzsche, Abulad finds premium in the via negativa for being the sole path to the via positive-which is the task of cleansing and rebuilding - to be a child again. True enough, nothing will be new and everything will just occur in vicious and stagnant routines if we will all think and act like stern, proud and stubborn adults.

The via positiva rises after desecration and demythologizing where there is enough space to make adjustments and create new spaces on account of changing times. This second phase of the dialectic, I believe, is postmodernism's redeeming grace or, if I may call, the saving parachute from useless rhetorical returns. Without a via positiva, no genesis of a new philosophical age is possible. I modestly proclaim this personal position in the spirit of Abulad's openness as he would certainly allow me to assume that this via positiva is intended to effectuate fresh starts without compromising any of these two equally important things. First is that every man remains sane, human and humane. Second, Abulad invokes the Kantian idea of Pure Reason, which is capable of being a critique of its own. It might be true that postmodernism had become incredulous to modern anthropocentricism, but it would never-ever lose its faith in knowledge, and more so in humanity. Echoing Abulad in "Postmodern Critique and the Ethics of Postmodernism": "... it is this very appreciation of the ultimate rootlessness of knowledge, that, in an instant, produces in the new consciousness its feeling of apodicticity, not only the feeling of apodicticity but also its sense of limitless creativity, the air that liberates the soul and accounts for the free spirits." 4

On the above note, it is clear that the via positiva is a reconstruction that aims not to disregard but to broaden the classical conception of

${ }^{3}$ Ibid., 27.

4 Romualdo E. Abulad, "Postmodern Critique and the Ethics of Postmodernism," Karunungan: A Journal of Philosophy, 19 (2002), 87.

(c) 2019 Fleurdeliz R. Altez-Albela

https://www.kritike.org/journal/issue 25/altez-albela december2019.pdf

ISSN 1908-7330

(cc) BY-NC-ND 
knowledge from being a science towards an insightful quest and take of an authentic life. In the postmodern times, one is authentically wise (enlightened), when s/he in the face of truth, can accept his/her profoundlearned ignorance that "debunks all obstacles ... for limitless creativity and productivity."

Thus, the postmodern project is a recreation of this profound sense of freedom and creativity that makes man neither wobbly in perception of facts nor deceitful for having gone through all thinkable adversities. The postmodern attitude, for Abulad, is grounded in "truths" that respect the outcomes of all beginnings: be it from the East or West, ancient or new, right or left, good or evil-as we have already moved on from the above dichotomies. In a certain sense, postmodernism reprises Pure Reason which shifts from being a purely inductive system to one that is dialogical. This is a result of Pure Reason's self-criticism. This dialogical shift, then, further results in a consciousness that is integral, holistic, global, dynamic, and evolutionary. Human reason becomes interpretative, ever understanding and accepting. It is also in this context that postmodernism refuses to define what is human yet fostering the humane.

I believe that, for Abulad, postmodernism has a radical pedagogical purpose, as it guides us young (sometimes errant) lovers of wisdom understand where we stand in the midst of our tasks. Abulad, the sober soul, helps us make sense of what we are doing. Armed with his knowledge of Eastern and Western thoughts, as well as ancient and contemporary philosophies, Abulad poured everything into his scholarship, even to the point of transgressing well-guarded philosophical tenets, in order to show the essence of dialogue and find truth even in little things.

The postmodern attitude, however, is not antithetical to discipline and rigor. This Abulad has demonstrated not only through his scholarship and teaching, but also through the religious life he has chosen. As a religious formator, Abulad's postmodern disposition blended well with the value formation within the religious community, as his seminarians and confreres could attest. Abulad's postmodern eyes are critical eyes; when he calls you out for erring in class or in writing, you are assured that he means well, as his eyes could attest.

For me, his eyes would always be postmodern, because his gaze is a glimpse of his soul that is remarkably open, "inclusive rather than exclusive, welcoming rather than rejecting, compassionate rather than egoistic." 5 I must say that his postmodern eyes have always seen me as a human being, more than a "budding scholar." Probably, that must be so because beyond just giving a estimative stare, he watched me, and each of us, grow. And as he

${ }^{5}$ Abulad, "What is Postmodernity?," 33.

(c) 2019 Fleurdeliz R. Altez-Albela

https://www.kritike.org/journal/issue 25/altez-albela december2019.pdf

ISSN 1908-7330

(cc) BY-NC-ND 


\section{ABULAD'S POSTMODERN EYES}

lovingly gazed at how we make and break our lives, these eyes have silently spurred us to go to places, find our respective joys and our own spaces under the sun be it philosophical or otherwise.

In the most personal part of this essay, allow me to thank Brother, Ninong Romy, for the grace of freedom, for that open-space and appreciation, because they have led me to places, to my narrative, to my happiness. Danke. Maraming Salamat po!

Department of Philosophy, University of Santo Tomas, Philippines

\section{References}

Abulad, Romualdo E., "Postmodern Critique and the Ethics of Postmodernism," Karunungan: A Journal of Philosophy, 19 (2002).

"What is Postmodernism?" Karunungan: A Journal of Philosophy, 17 (2000). 